\title{
Relationships between Oak powdery mildew incidence and severity and commensal fungi
}

Article

Accepted Version

Topalidou, E. T. and Shaw, M. W. (2016) Relationships between Oak powdery mildew incidence and severity and commensal fungi. Forest Pathology, 46 (2). pp. 104-115. ISSN 1437-4781 doi: https://doi.org/10.1111/efp.12218 Available at https://centaur.reading.ac.uk/40652/

It is advisable to refer to the publisher's version if you intend to cite from the work. See Guidance on citing.

To link to this article DOI: http://dx.doi.org/10.1111/efp.12218

Publisher: Wiley-Blackwell

All outputs in CentAUR are protected by Intellectual Property Rights law, including copyright law. Copyright and IPR is retained by the creators or other copyright holders. Terms and conditions for use of this material are defined in the End User Agreement.

www.reading.ac.uk/centaur 
Central Archive at the University of Reading

Reading's research outputs online 


\section{Relationships between Oak powdery mildew incidence and severity and commensal fungi.}

Eleni T. Topalidou, and Michael W. Shaw ${ }^{\mathrm{a}}$

${ }^{a}$ School of Biological Sciences, University of Reading, Lyle Tower, Whiteknights,

Reading RG6 6AS, UK.

${ }^{\mathrm{b}}$ Hellenic Agricultural Organization “DEMETER”, Forest Research Institute, Thessaloniki, GR-57006 Vassilika, GREECE

${ }^{\mathrm{a}}$ Correspondence should be addressed to: elenitopalidou@gmail.com, eltopal@fri.gr

Keywords: powdery mildew, commensal fungi, interacting fungi, Erysiphe alphitoides 


\section{Summary}

Oak (Quercus robur) powdery mildew is a common and damaging fungal disease. In a local survey at Reading, UK, oak powdery mildew was common on trees of all heightclasses but was most common on trees of $3-9 \mathrm{~m}$. A variety of other fungal species were commonly found growing in association with oak powdery mildew colonies. The abundance of such fungi was estimated through stratified sample surveys for 2.5 years. The taxa most commonly associated with oak powdery mildew were Acremonium sp., Trichoderma sp., Ampelomyces/Phoma sp. and Leptosphaerulina australis. Nearly 90\% of mildew colonies were associated with L. australis, which is not generally considered as a mycoparasite or antagonist, in contrast with the other three fungi. Abundance varied between June and October surveys. Acremonium sp. abundance was greater in summer samplings whereas L. australis and Trichoderma sp. abundances were greater in autumn samplings. Ampelomyces/Phoma sp. was never observed in the absence of powdery mildew. Relationships between the mildew-associated fungi and oak powdery mildew appeared curved and differed significantly between sampling years. L. australis was positively correlated with the other three associated fungi studied when powdery mildew was also present. The variety and high population densities of the mildewassociated fungi suggest that they may be important in determining the final density of oak mildew and the damage caused by it. 


\section{Introduction}

Oak powdery mildew affects oaks of all species, ages and geographical origins, but the impact of the disease differs depending on the species. Three species are responsible for oak powdery mildew in Europe. The most common is Erysiphe alphitoides (Griffon \& Maubl.) U. Braun \& S. Takam.. Far less frequent are E. hypophylla (Nevod.) U. Braun \& Cunningt. and Phyllactinia guttata (Wallr.) Lév. (sensu lato, including P. roboris (Gachet) S. Blumer) (Mougou et al., 2008; Mougou-Hamdane et al., 2010). A fourth species, not previously reported in Europe, was recently found in France under the name E. quercicola (Mougou-Hamdane et al., 2010). E. alphitoides is the most prevalent and damaging species. The host range of E. alphitoides lies mainly in the genus Quercus, with Q. robur being the most susceptible species (Ayres, 1976; Ufnalski and Przybyl, 2004), and oak powdery mildew is ubiquitous and abundant on Q. robur in the British Isles. Infection by powdery mildew seriously reduces the life-span of leaves (Hajji et al.

2009). Seedlings and young oak trees in forests (as well as in nurseries and plantations) are very susceptible to the disease (Ufnalski and Przybyl, 2004); growth of young stands is substantially retarded; and infection may cause severe seedling mortality (Soutrenon, 1998; Desprez-Loustau et al, 2014). Repeated attacks by E. alphitoides in combination with attacks by other pathogens and/or insects can reduce the vigour of mature trees (Hajji et al., 2009). In most European areas where oaks are grown, the combined effects of powdery mildew with other fungal and insect infestations are implicated in oak decline (Ufnalski and Przybyl, 2004; Marcais and Desprez-Loustau, 2014).

In Europe, oak mildew epidemics usually start late in spring, as the spring shoots develop (Marcais et al., 2009). Young, expanding and developing leaves are very susceptible to the disease but their susceptibility decreases as leaves mature (Edwards 
and Ayres, 1982; Marcais and Desprez-Loustau, 2014). Consequently, the pathogen has a nearly monocyclic infection cycle. The disease can occasionally be severe if epidemics occur early in spring (Marcais et al., 2009) when high levels of inoculum coincide with the presence of susceptible leaf tissues. Host-pathogen synchrony in spring appears to regulate disease severity (Desprez-Loustau et al., 2010). Disease prevalence is greater on the second and the third leaf flushes produced between the end of June and August (Marcais et al., 2009); these leaves tend to be very__severely infected, presumably because inoculum is abundant as they expand. Host-pathogen synchrony is probably responsible for the lower disease severity observed on large trees since the second and third flush leaves are a smaller proportion of the total leaf area produced during the season (Bréda et al., 1995; Marcais et al., 2009). Chasmothecia, the sexual fruiting bodies which contain asci, are abundant on falling leaves in the autumn. However, the role of ascospores in the epidemiology of the disease has been controversial. For a longtime __ Initial infections were previously believed to start from overwintering mycelium in buds (Kerling, 1966; Nef and Perrin, 1999). However, Marcais et al. (2009) found such initial infections to be very_infrequent in spring, and ascospores, which are widely dispersed by wind, to be the most common source of inoculum for the primary spring infections.

Aerial leaf surfaces of all plants are naturally inhabited by numerous microorganisms (Gowdu and Balasubramanian, 1988; Jumpponen and Jones, 2010; Cordier et al., 2012) which not infrequently provide partial control of some plant pathogens (Rishbeth et al., 1988). Powdery mildews are ectotrophic pathogens and therefore in close contact with and potentially attacked by the phylloplane microflora (Bélanger et al., 1998; Bélanger and Labbé, 2002). Organisms from diverse biological groups 
(bacteria, fungi, arthropods) have been reported to actively antagonise powdery mildews (Bélanger and Labbé, 2002) by parasitism, antibiotic production, or induction of hostresistance (Blakeman and Fokkema, 1982; Bélanger et al., 1998; Kiss, 2003; CortesPenagos et al., 2006). These modes of action are not mutually exclusive (Kiss, 2003). The most common fungal antagonists reported in natural association with mildew species are Ampelomyces spp., Tilletiopsis spp., Cephalosporium spp., Cladosporium spp. (Kiss, 2003), Acremonium alternatum (Malathrakis, 1985), Dissoconium aciculare, Aphanocladium album and Acremonium byssoides, Pseudomyza flocculosa (Kiss, 2003). Species of Trichoderma, Fusarium and Penicillium chrysogenum have not been found to be mycoparasites of any powdery mildew species in nature but have been successfully tested for anti-powdery mildew activity in field and glasshouse trials (Kiss, 2003). Ampelomyces quisqualis is the only mycoparasite which has been reported from oak specimens $(Q$. robur and $Q$. petrea) infected with E. alphitoides (Kiss, 1998). There are no effective methods to manage oak powdery mildew within forest environments and therefore, biological control is an attractive option. In order to explore this option, it is essential to understand the biology and ecological setting of the phyllosphere organisms which naturally co-exist with powdery mildew and how they vary throughout the season (Heuser and Zimmer, 2002; Kaneko et al. 2003; Osono, 2009; Jumpponen and Jones, 2010).

Our underlying hypotheses were that the abundance of mildew on oak leaves would form a substantial resource for other fungi, and that these would limit the abundance of mildew. Therefore the primary purpose of the present study was to identify the main fungi which are naturally associated with oak powdery mildew, to record their abundance and the appropriate scale of study. A secondary purpose was to examine how 
the abundance of mildew-commensal fungi was related to the abundance of powdery mildew and environmental factors.

\section{Materials and methods}

\section{1 Sampling}

Samples were collected from two areas on the campus of the University of Reading (Fig. 1) in areas where oak trees of various species (mainly Quercus robur but also Q. cerris, Q. canariensis, $Q . \times$ turneri, $Q . \times$ hispanica “Lucombeana”, Q. nigra, $Q$. dentata, , $Q$. castanifolia, Q. ilex,) and other tree species are frequent. Leaf samples were collected from 11 trees (Q. robur) in summer (04/07/2005, 15/06/2006 depending on the appearance of powdery mildew symptoms on leaves) and autumn (12/10/2004, $03 / 10 / 2005,28 / 09 / 2006)$. The trees were arbitrarily selected within each of the two areas so as to include trees falling into each of three height-classes (1-3m, 3-9m and 9-12m). On each tree, powdery mildew severity was assessed on a total of 50 leaves, as follows: From each tree, 25 branches (of $2-3 \mathrm{~cm}$ in diameter and located $1-4 \mathrm{~m}$ above the ground) were collected arbitrarily from the periphery of the canopy and a single leaf was sampled at random from two shoots of each branch; one from the right of the branch and one from the left. Leaves were assessed on both the upper and the lower surface. For practical reasons it was not possible to sample the upper canopy of the large trees. To study associations between mildew and other organisms, two out of the 25 previously assessed branches (each bearing about 10 leaves) were selected and sticky tape impressions were prepared as described in the next section. From each of the 10 leaves on a branch, two sticky tape impressions were prepared within $24 \mathrm{~h}$ of collection, one from the upper and one from the lower leaf surface. The impressions were made under 
the binocular microscope from sporulating zones of the leaves where these were present; since the leaves on each branch exhibited different levels of powdery mildew infection, some impressions were also made from leaves which had no visible powdery mildew colonies.

\subsection{Assessment}

Powdery mildew was assessed visually by estimating the percentage of the leaf area which was covered by $E$. alphitoides mycelium on a scale $0-100 \%$ : 0 for no visible mildew spots and $100 \%$ for full coverage of the leaves by mildew. The assessment of fungi growing on $E$. alphitoides colonies was made by examining one transect $(25 \mathrm{~mm} \mathrm{x}$ $0.2 \mathrm{~mm}$ ) across the long axis of each slide under a light microscope with a $10 \mathrm{x}$ or $40 \mathrm{x}$ objective and scoring the abundance of characteristic features of each commensal fungus on a four-point scale, 0 (none), 1 (rare), 2 (many) and 3 (abundant) (Fig 2) in eachtransect. Fungi were visually assigned to morphological groupings. Isolation of representatives of the most common fungi seen was attempted on Potato Dextrose Agar (PDA) and/or Tap Water Agar (TWA), both including $0.1 \mathrm{~g} / \mathrm{L}$ streptomycin and $0.1 \mathrm{~g} / \mathrm{L}$ penicillin. Spores, mycelium and other fungal structures (e.g. pseudothecia) were picked up with a fine needle and deposited either directly on the medium or into a small droplet of sterile water on the medium, which was then spread over the surface with a glass spreader. Plates were incubated in darkness at $18^{\circ}-20^{\circ} \mathrm{C}$ and checked at 2-3day intervals. Fungal colonies seen were sub-cultured repeatedly on PDA until they appeared to be visually stable. Multiple morphological types on a plate were separated by serial dilutions of spores. For long term storage the commensal fungi were subcultured onto malt extract agar (MEA) slopes and kept under oil at $3{ }^{\circ} \mathrm{C}$. Distinct groups of fungi were identified as far as possible to genus level based on original appearance 
and culture morphological characteristics, using literature keys and descriptions (Gams, 1971; Ellis and Ellis, 1997; Barnett and Hunter, 1998; Gams and Meyer, 1998). Selected samples were further identified by using the ITS sequence of ribosomal DNA (Schorch et al., 2012). Mycelium and stroma were scraped from cultures, ground in liquid nitrogen and DNA extracted using a DNEasy Plant kit (Qiagen, Crawley, West Sussex, UK). ITS 5.8S sequences were amplified from two independent isolates of typical morphology using ITS4 and ITS5 universal primers according to the methods of Gardes and Bruns (1993), White et al. (1990) and Abler (2003). The amplicons were sequenced commercially (Macrogen, Seoul, Korea).

\subsection{Statistical analysis}

The effects of environmental and host factors on mildew severity, the abundance of commensal fungi, and their associations with powdery mildew severity were evaluated by REML models using the facilities in Genstat v11 (VSN International Ltd, Hemel Hempsted-Hertfordshire, UK). In the overall REML analysis, the season, height-class of trees, and leaf-surface were specified as fixed factors, with sampling year and location as random factors. Estimates of the percentage of powdery mildew severity were transformed to logits and conidia counts were transformed into $\log _{\mathrm{e}}$ for analysis. Zero values were regarded as 0.001 for conversion to the log scale.

Relationships between the fungi associated with E. alphitoides were investigated by linear regression analysis. Powdery mildew severity was related to the score of each associated fungi by conventional stepwise regression analysis. The response (dependent) variable was the mean score of each commensal fungus on a tree in each survey, so $\mathrm{n}=$ 
55, and powdery mildew severity was set as an explanatory variate- Parallel curve analysis (Mead et al., 2002, chap. 10) was used to determine whether separate regression models were needed in each surveyed year. Relationships between the commensal fungi surveyed were also investigated by parallel curve analysis.

\section{Results}

\subsection{Identification}

Specimens of the powdery mildew population from three out of the eleven sampled trees were sequenced (S. Takamatsu, Mie University, Tsu, 514-8507, Japan, unpublished data). The sequences indicated that only E. alphitoides s. str. (Takamatsu et al., 2007) Not included in Refs. was present.

Most powdery mildew colonies examined were associated with other fungi, even when first visible, during the summer assessment. Five morphological types were common (Fig. 2): Trichoderma sp.; Ampelomyces/Phoma sp.; Acremonium sp.; a Tilletiopsis-like group, and Leptosphaerulina sp.. Patches of powdery mildew colonies containing Leptosphaerulina sp. were often visibly browned. A minority of undetermined spores of various types were recorded but were insufficiently common or distinctive for meaningful analysis.

Isolations from the Trichoderma-like spores produced two distinct types of culture, differing in colour and growth-rate (Genbank KM406100, KM406101). Their highest match was at 98\% similarity with Genbank sequences (AY605750, AY605742, AY605733, AY222349, AB297802) identified as Hypocrea lixii (= Trichoderma harzianum) and Trichoderma sp.. The Acremonium-like sequences (Genbank 
KM406102, KM406103, KM406104) had a the highest match with Genbank sequences identified as Acremonium sp. (Genbank AM262391, AM262392) at up to 98\% similarity. Identification to species level was not possible. Leptosphaerulina sp. isolates were identified by Dr B. Spooner of CAB IMI as L. australis. Sequences (Genbank KF275143, KF275144) matched at 99\% similarity with? Genbank sequences identified as L. trifolii (GenBank AY131203), which is considered a synonym of L. australis (Irwin and Davis, 1985 Not in Refs.; Abler 2003).

Repeated attempts to isolate Ampelomyces quisqualis on artificial media were fruitless. Consequently, its presence in our study was based on the characteristic development of the pycnidial forms. However, distinction of A. quisqualis from Phoma species is difficult under light microscopy and therefore, this morphological group was recorded as Ampelomyces/Phoma.

\subsection{Powdery mildew incidence and severity}

Powdery mildew incidence varied substantially between the sampled years but considerable variation was also attributed on tree specific factors (Table 1). Powdery mildew severity varied substantially between the sampled years but substantial differences were also spotted in the disease levels within the canopy of single trees. The extra variance among trees within a location was negligible (Table 1). The two locations studied differed no more than expected from differences among trees within the same location (Table 1). However, both powdery mildew incidence and severity were highest in autumn (Fig. 3, 4; $P<0.001$, Fisher exact test) and were also affected significantly by the tree height-class; $3-9 \mathrm{~m}$ trees were more diseased than the other two height classes (Fig. 3, 4; $P<0.001$, Fisher exact test). 


\subsection{Abundance of commensal fungi}

Powdery mildew colonies were already associated with a range of other fungi (Fig. 5).

L. australis, Trichoderma sp., Ampelomyces/Phoma sp. and Acremonium sp. were commonly associated with powdery mildew on all sampling occasions (Fig. 5, 6). Variance between trees was very low whereas there was substantial variation in the abundance scores of all commensal fungi between the different occasions of specimen collection and within the canopies of the trees (Table 2).

Acremonium sp. was common in all samples but abundance varied between years (Fig. 6). The incidence and abundance score of Acremonium sp. differed between seasons $(P<0.001$, Fisher exact test): abundance scores were always higher in the early summer samplings (Fig. 6). Acremonium sp. abundance scores greater than 2 were rare but associated with lower powdery mildew densities on the same trees (Fig. 7).

Ampelomyces/Phoma sp. abundance scores differed between years (Figs. 6). Ampelomyces/Phoma scores were larger in autumn samplings but not significantly so compared to the summer samplings. The taxon was never observed in the absence of powdery mildew (Table 3) and was never observed at high population densities (score $>2$ ) even when powdery mildew severity was high (Fig. 7). Abundance score did not differ significantly between the two leaf-surfaces $(P>0.05$, Fisher exact test).

L. australis was abundant each year and was associated with $91 \%$ of powdery mildew colonies examined. Although, rarely, L. australis ascospores were observed on leaf areas free of powdery mildew colonies, the fungus was more frequent on leaves with powdery mildew $(P<0.001$, Fisher exact test; Table 3$)$. L. australis incidence on

mildewed leaves was greater on 3-9 m trees (interaction $P=0.006$, Fisher exact test). $L$. 
australis scores were higher in autumn $(P<0.001$, Fisher exact test; Fig. 6$)$ and increased over the observation period (Fig. 6). The mean powdery mildew severity was slightly greater with greater L. australis scores in the 11 tree samples (Fig. 7), but the variation in powdery mildew severity was reduced in samples with greater L. australis scores (Fig. 7).

About $80 \%$ of powdery mildew colonies examined were associated with Trichoderma sp. Its incidence and population score were larger in autumn $(P<0.001$, Fisher exact test; Fig. 6). The upper leaf surface was more intensively colonised by Trichoderma sp. than the lower $(P<0.001$, Fisher exact test; Table 3$)$. Powdery mildew severity was greatest and most variable at intermediate Trichoderma scores (Fig. 7).

\subsection{Correlations among powdery mildew and commensal fungi}

Our hypothesis was that commensals would be more common when powdery mildew severity was greater and so provided a larger resource. Both slope and intercept of the relationship between powdery mildew severity and commensal fungus score varied between years for all commensals $(P \leq 0.001$; Fig. 8). Season, height-class and leaf surface did not significantly improve the model fit. Higher powdery mildew severities were associated with intermediate Acremonium sp. and Trichoderma sp. scores (Fig. 7, 8). The slope of regressions of Trichoderma sp. score on powdery mildew severity were strong and positive in 2005, 2006 and negative but not strong in 2004 (Fig. 8). However, the overall interaction was strong (Wald-test interaction $P<0.001$ ). The relationships of Trichoderma sp. and Acremonium sp. scores to powdery mildew severity appeared curved (Fig. 7, 8), with very high scores associated with moderate powdery mildew severity $(>60 \%)$. The slope and intercept of Acremonium sp. score were negative in 2004 but positive in 2005 and 2006 (Wald-test interaction $P \leq 0.05$; Fig. 
8). Ampelomyces/Phoma sp. scores were low in the years studied (Fig. 6, 8) and although the association to powdery mildew severity was positive in all years (Fig. 8), the overall interaction was not significant $(P>0.1)$. The intercept and slope for $L$. australis score were positive in the years studied (Fig. 8) and higher L. australis scores were associated with lower powdery mildew severity (>40\%) (Fig. 7). Such association was strong in 2006 (Fig. 8) and the overall interaction was also strong (Wald-test interaction $P<0.001)$.

There were weak but significant associations between L. australis and the other three fungi associated with powdery mildew (Fig. 9). Separate regression lines for cases where powdery mildew was present and where it was absent greatly improved the fit $(P<0.001) . \quad$ Acremonium sp., Ampelomyces/Phoma sp. and Trichoderma sp. were positively associated with L. australis when powdery mildew was also present (Fig. 9). No statistically significant linear dependence of the mean scores of Acremonium sp., Ampelomyces/Phoma sp. or Trichoderma sp. on L. australis scores was detected when powdery mildew colonies were not present (Fig. 9). The three-way interaction between Ampelomyces/Phoma sp., L. australis score and powdery mildew presence was significant (Wald-test $P<0.05$ ). The same interaction was also significant for Trichoderma sp. (Wald-test $P<0.001$ ).

\section{Discussion}

Powdery mildew severity varied much more across years than among trees, and there was only slightly more variation among trees than expected from the variation between leaves from the same tree. Powdery mildew severity is critically influenced by the time 
between flushing of shoots and maturation of the leaves (Edwards and Ayres, 1982; Marcais et al. 2009) because oak leaves greatly increase their resistance to powdery mildew infections after a few weeks (Edwards and Ayres 1981; Marcais et al. 2009). Competition between powdery mildew species and competition, parasitism or resistance induction by other phylloplane fungi may also affect powdery mildew severity (Mougou et al., 2010). Along with as E. alphitoides, various other powdery mildew species have a host range including Quercus spp. (Takamatsu et al., 2007) Not in Refs.. The coexistence of visually similar but distinct species of powdery mildew on oak could confuse study of the population dynamics, but our limited sample suggests at least a strong preponderance of E. alphitoides in this study area.

Oak powdery mildew colonies co-existed with several other fungi. Four different morphological types of fungus co-occuring with powdery mildew colonies were commonly observed. Most colonies co-existed with several of them. The least common was an Ampelomyces/Phoma-like species. These have been associated with direct mycoparasitism of powdery mildews (Kiss, 1998). Two of the remaining three morphological types identified (Trichoderma sp. and Acremonium sp.) have often been found to actively antagonise other fungi, including powdery mildews, by antibiosis or direct parasitism (Malathrakis, 1985; Elad, 2000; Not in Refs. Kiss, 2003); however, based on this study no definite inferences can be made regarding Trichoderma sp. and Acremonium sp. modes of action. The final fungus, identified as L. australis, has not been mentioned before in association with powdery mildew. In parallel work with this survey, L. australis was shown to reduce infection of oak leaves by powdery mildew in controlled inoculations (Topalidou, 2008)_Not in Refs. although the mechanism is unknown. Leptosphaerulina sp. are reported as weak pathogens or as saprobes. In some 
studies $L$. chartarum has been shown to survive as a symptomless endophyte in its host (Suryanarayaman and Murali, 2006; Salvanathan et al, 2011). The same species (Wu et al, 2013) has been shown to produce xylanotic enzymes which enhanced plant defence against stress and disease. In view of this, it would be interesting to explore the possible endophytic existence of $L$. australis in oak leaves in view of its common association with oak powdery mildew. The incidence and severity of commensal fungi may depend on or influence population densities of powdery mildew. Powdery mildew infection alters the physiological condition of leaves which will in turn influence microbial community structure and growth on the phylloplane. Hyper-parasitic fungi are likely to show density-dependent relations to powdery mildew severity; neutrally associated fungi may depend on powdery mildew without influencing its density. In this study, the fungi associated with powdery mildew, apart from Ampelomyces/Phoma sp., came from taxa not reported to be specialised mycoparasites and having wide host and geographic ranges.

According to Sadaka and Ponge (2003) the appearance of Acremonium sp. coincided with the senescence of the leaves of holm oak. In this survey, we found Acremonium sp. more abundant in summer. Trichoderma species are known as secondary colonisers of various forest litters (Domsch et al, 1980). Six different Trichoderma species were reported on leaves of $Q$. rotundifolia at different stages of leaf senescence (Sadaka and Ponge, 2003). In this study Trichoderma sp. was recorded on living leaves infected with powdery mildew, but the mean score was higher in autumn (Figs 5, 6), shortly before leaf-fall.

L. australis was very commonly found in association with oak powdery mildew. It was more abundant at high powdery mildew severity (Fig. 7, 8), although the 
association was weak. In laboratory tests, inoculation of young oak leaves with $L$. australis reduced powdery mildew colonies and appeared to colonise other powdery mildew species (P. aphanis, P. xanthii) (Topalidou 2008, pp 199-205) Not in Refs.. L. australis has been recorded repeatedly in co-existence with many other fungal genera on Q. macrocarpa leaves (Jumpponen and Jones, 2010) but it has not been reported as a mycoparasite or antagonist of any pathogen. However, several species of Leptosphaerulina have been reported in association with diseases of turf-grasses such as anthracnose, Pythium blight and Pyricularia grisea (Dernoeden, 2002) Not in Refs.. L. australis in particular has been regularly found in conjunction with other pathogens such as Fusarium spp. and Sclerotinia homoeocarpa (Abler, 2003).

With the partial exception of L. australis, populations of powdery mildewassociated fungi fluctuated greatly over the study period (Fig. 6). Low levels of Ampelomyces/Phoma sp. in 2006 (Fig. 6) were presumably related to climatic factors, since Ampelomyces/Phoma sp. is favoured by high RH (Jarvis and Slingsby, 1977; Schweigkofler, 2006) and the summer of 2006 was extremely hot and dry.

This survey showed seasonal and within-tree effects on powdery mildew severity to be more important than variation between $Q$. robur specimens. It indicates that powdery mildew colonies on oak leaves are, from their first appearance, very frequently associated with other fungi, some of which either attack the powdery mildew directly (eg. Ampelomyces/Phoma sp.), or may render leaves less susceptible to attack. Therefore, they are important elements in the phylloplane community. Acremonium sp. and Trichoderma sp. were rarer when powdery mildew was more severe in the early season, but commoner when powdery mildew was more severe in the late season, although the shifts were not always significant. A hypothesis to explain this would be 
that the initial association was driven by factors independent of or restricting powdery mildew severity, such as surface wetness, but that later they were either consuming powdery mildew. Ampelomyces/Phoma and L. australis populations were always positively correlated with powdery mildew severity, although again not always significantly. It is possible that powdery mildew represented a nutrient resource for both organisms, though L. australis is known purely as a saprophyte or weak plant pathogen.

\section{Acknowledgements}

Financial support by IKY, the Greek State Scholarship Foundation, is duly acknowledged for the first author. Dr. Glynn Percival is duly acknowledged for kindly providing the oak seedlings. We also thank Levente Kiss, Hungarian Academy of Sciences for advice and comment during the work. Professor Susumu Takamatsu, Mie University, is also duly acknowledged for his help in identifying the species of powdery mildew samples. Dr.

Giannis Meliadis, Hellenic Agricultural Organisation Demeter, Forest Research Institute of Thessaloniki, is duly acknowledged for helping in mapping the trees in Fig. 1.

\section{References}

Abler, S. W. 2003: Ecology and Taxonomy of Leptosphaerulina spp. associated with turfgrasses in the United States, MSc thesis, Virginia Polytechnic Institute and State University, Blacksburg, Virginia, USA.

Ayres, P. G. 1976: Natural resistance to oak mildew. Arboricultural Journal 3, 23-29.

Barnett, H.L. and Hunter, B.B. 1998: Illustrated Genera of imperfect Fungi. 4rth ed., St. Paul Minnesota, USA: APS Press. 
Bélanger, R. R.; Dik, A. J. and Menzies, J. G. 1998: Powdery mildews: Recent advances towards integrated control. In Plant-microbe Interactions and Biological Control. Ed. By Boland, G. J. and Kuykendall, L. D. Florida, USA: CRC Press.

Bélanger, R. R. and Labbé, C. 2002: Control of powdery mildews without chemicals: Prophylactic and biological alternatives for horticultural crops. In The Powdery Mildews: A Comprehensive Treatise. Ed. by Bélanger, R. R., Bushnell, W. R, Dik, A. J. and Carver T. L. W., St. Paul, Minnesota, USA: APS Press, pp 256-267.

Blakeman, J. P. and Fokkema N. J. 1982: Potential for biological control of plant diseases on the phylloplane. Annual Review of Phytopathology 20, 167-192.

Bréda N., Granier A. and Aussenac G., 1995: Effects of thinning on soil water balance and trees water relations, transpiration and growth in an oak forest (Quercus petraea). Tree Physiology 15, 295-306.

Cordier, T., Robin, C., Capdevielle, X., Fabreguettes, O., Desprez-Loustau, M.L. and Vacher, C. 2012: The composition of phyllosphere fungal assemblages of European beech (Fagus sylvatica) varies significantly along an elevation gradient. New Phytologist 196, 510-519

Cortes-Penagos, C., Olmedo-Monfil, V. and Herrera-Estrella, A: 2006: The nature of fungal mycoparasitic biocontrol agents. In Biological Control of Plant Diseases. Ed. By Chincholkar, S. B. and Mukerji, K. G. Philadelphia, USA: Haworth Press.

Desprez-Loustau M.L.;,Vitasse Y., Delzon S., Capdevielle X., Marçais B. and Kremer A. 2010: Are plant pathogen populations adapted for encounter with their host? A 
case study of phenological synchrony between oak and an obligate fungal parasite along an altitudinal gradient. Journal of Evolutionary Biology 23, 87-97

Desprez-Loustau, M.L., Saint-Jean, G., Barres, B., Dante, C.F., Dutech, C. 2014: Oak powdery mildew vhanges growth patterns in its host tree: host tolerance response and potential manipulation of host physiology by the parasite. Annals of Forest Science $71,563-573$

Domsch, K.H., Gams, W. and Anderson, T.H. (1980): Compendium of soil fungi, vol. 1. Academic Press, New York.

Edwards, M.C. and Ayers, P.G. 1981: Cell death and cell wall papillae in the resistance of oak species to powdery mildew disease. New Phytologist 89:411-418.

Ellis, M.B. and. Ellis, J.P. 1997: Microfungi on Land Plants. Richmond Publishing Co. Ltd. Slough.

Gams, W. 1971: Cephalosporium-artige Schimmelpilze (Hyphomycetes). Stuttgart, Germany, Gustav Fischer Verlag.

Gams, W. and Meyer, W. 1998: What exactly is Trichoderma harzianum Rifai?. Mycologia 90, 904-915.

Gardes, M. and Burns, T. D. 1993: ITS primers with enhanced specificity for basiodiomycetes-application to the indentification of mycorrhizae and rusts. Journal of Ecology, 2, 113-118. 
Gowdu, B. J. and Balasubramanian, R. 1988: Role of phylloplane micro-organisms in the biological control of foliar plant diseases. Zeitschraft für Pflanzenkrankheiten und Pflanzenschutz 95, 310-331.

Heuser, T. and Zimmer, W. 2002: Quantitative analysis of phytopathogenic ascomycota on leaves of penduculate oaks (Quercus robur L.) by real-time PCR. FEMS Microbiology Letters 209, 295-299.

Hajji, M., Drever, E. and Benoit M. 2009: Impact of Erysiphe alphitoides on transpiration and photosynthesis in Quercus robur leaves. European Journal of Plant Pathology 125, 63-72.

Jarvis, W.R. and Slingsby, K. (1977). The control of powdery mildew of greenhouse cucumber by water spray and Ampelomyces quisqualis. Plant Disease Reporter, 61, 728-730.

Jumpponen, A. and Jones, K. L. 2010: Seasonally dynamic fungal communities in the Quercus macrocarpa phyllosphere differ between urban and nonurban environments. New Phytologist 186, 496-513

Kaneko, R., Kakishima, M. and Tokumasu, S. 2003: The seasonal occurrence of endophytic fungus, Mycosphearella buna, in Japanese beech, Fagus crenata. Mycoscience 44, 277-281.

Kerling, L.C.P. 1966: The hibernation of the oak mildew. Acta Botanica Neerlandica 15: 76-83.

Kiss, L. 1998: Natural occurrence of Ampelomyces intracellular mycoparasites in mycelia of powdery mildew fungi. New Phytologist 140, 709-714. 
Kiss, L. 2003: A review of fungal antagonists of powdery mildews and their potential as biocontrol agents. Pest Management Science 59, 475-483.

Malathrakis, N. E. 1985: The fungus Acremonium alternatum Linc: Fr., a hyperparasite of the curcubits powdery mildew pathogen Sphaerotheca fuliginea. Zeitschrift für Pflanzenkankheiten und Pflanzenschutz 92, 509-515.

Marcais, B.; Kavkova, M. and Desprez-Loustau, M-L. 2009: Phenotypic variation in the phenology of ascospore production between European populations of oak powdery mildew. Annals of Forest Science 66, 814-822.

Marcais, B. and Desprez-Loustau, M-L. 2014: European oak powdery mildew: impact on trees, effects of environmental factors, and potential effects of climate change. Annals of Forest Science. 71, 633-642

Mead, R., Curnow R. N. and Hasted A. M. 2003. Statistical methods in agriculture and experimental biology. Chapman and Hall: London.

Mougou, A.; Dutech, C. and Desprez-Loustau, M-L. 2008: New insights into the identity and origin of the causal agent of oak powdery mildew in Europe. Forest Pathology 38, 275-287.

Mougou-Hamdane, A.; Giresse, X.; Dutech, C. and Desprez-Loustau, M-L. 2010: Spatial distribution of lineages of oak powdery mildew fungi in France, using quick molecular detection methods. Annals of Forest Science 67, 212

Nef, L. and Perrin, R. 1999: Practical handbook on damaging agents in the European forest nurseries. EU, Air 2-CT93-1694 project. European communities, Luxembourg. 
Osono, T. 2008: Endophytic and epiphytic phyllosphere fungi of Camellia japonica: seasonal and leaf age-dependent variations. Mycologia 100, 387-391.

Rishbeth, J.; Lumsden, R. D.; Gibbs, J. N.; Hamilton, W. D. and Cook, R. J. 1988: Biological control of air-borne pathogens. Philosophical Transactions of the Royal Society of London B 318, 265-281.

Sadaka, N. and Ponge J.-F. 2003: Fungal colonization of phyllosphere and litter of Quercus rotundifolia Lam.. in a Holm oak forest (High Atlas, Morocco). Biology and Fertility of Soils 39, 30-36.

Schoch, C. L., Seifert, K. A., Huhndorf, S., Robert, V., Spouge, J. L., Levesque, C. A.,Chen, W. and Fungal Barcoding Consortium. 2012. Nuclear ribosomal internal transcribed spacer (ITS) region as a universal DNA barcode marker for Fungi. Proceedings of the National Academy of Sciences, USA, 109, 6241-6246, doi: 10.1073/pnas.1117018109

Schweigkofler, W. (2006). Effects of fungicides on the germination of Ampelomyces quisqualis AQ10, a biological antagonist of the powdery mildew of the grapevine. Integrated Protection in Viticulture, IOBC/wprs Bulletin, 29, 79-82.

Selvanathan, S., Indrakumar, I. and Johnpaul, M. 2011: Biodiversity of the endophytic fungi isolated from Calotropis gigantea (L.) R. Br. Recent Research in Science and Technology, 3, 94-100.

Soutrenon, A. 1998: Une experimentation pluri-annuelle confirme l'impact de l'oïdium sur de jeunes sujets. Les cahiers du DSF, 1-2000 (la santé des forets [France] en 1997), pp. 93-94. Paris: Min. Agri. Peche (DERF). 
Soukup, F. 2005: Oak mildew-possibilities of its control. Journal of Forest Science 51, 195-202.

Suryanarayanan, T. and Murali, T.S. 2006: Incidence of Leptosphaerulina crassiasca in symptomless leaves of peanut in southern India. Journal of Basic Microbiology 46, 305-309.Topalidou, E. 2008: Ecology of oak powdery mildew Erysiphe alphitoides. $\mathrm{PhD}$ thesis, Reading.

Ufnalski, K. and Przybyl, K. 2004: Variability in morphology of Microsphaera alphitoides Griffon et Maubl. in Poland. Acta Societatis Botanicorum Poloniae 73, $233-237$

White T. J.; Bruns, T.; Lee, S.; Taylor, J., 1990: Amplification and direct sequencing of fungal ribosomal RNA genes for phylogenetics. In: PCR Protocols: A Guide to Methods and Applications. Ed. by Innis, M.A., Gelfand, D. H., Shinsky, J. J., White T. J., San Diego, USA: Academic Press, pp 315-322.

Wu, Q., Li, Y., Li, Y., Gao, S., Wang, M. Zhang, T. and Chen, J. 2013. Identification of a novel fungus, Leptosphaerulina chartarum SJTU59 and characterization of its xylanolytic enzymes. PLoS ONE 8, e73729. doi:10.1371/journal.pone.0073729 


\section{FIGURE CAPTIONS}

Fig. 1: Map of the sampled trees within the two examined locations (Harris Garden and Earley Gate) within the campus of the University of Reading (aerophotgraph was downloaded from Google Earth, 2008). Each of the trees was classified into one of three height-classes as follows: 3, 6 and 9 into 1-3m; 4, 5, 8 and 11 into 3-9m; $1,2,7$ and 10 into $9-12 \mathrm{~m}$.

Fig. 2: Panel of photos from the assessment of each morphological group of the commensal fungi. (a) Ampelomyces/Phoma sp.: (i) conidia exuded from pycnidia, (ii), (iii) pycnidia which grow superficially in/on or around powdery mildew hyphae. Scale bars equal to $10 \mu \mathrm{m}$. (b) Trichoderma sp.: (i) Trichoderma sp. spores and (ii), (iii) arrows pointing at Trichoderma sp. spores which were observed around powdery mildew conidia. Scale bars equal to $10 \mu \mathrm{m}, 20 \mu \mathrm{m}$ and $20 \mu \mathrm{m}$ respectively for (i), (ii) and (iii). (c) Acremonium sp.: (i) Acremonium sp. spores and (ii) arrows pointing at Acremoium sp. phialides and spores, emerging throughout a cluster of powdery mildew conidia. Scale bars equal to $10 \mu \mathrm{m}$. (d) L. australis: (i) ascospores emerging from the asci, (ii) ascospore attached on a powdery mildew conium and (iii) an L. australis ascospore close to powdery mildew mycelium. Scale bars equal to $10 \mu \mathrm{m}$.

Fig. 3 : Incidence of powdery mildew (\%) on oak leaves, averaged within each height-class of tree sampled on each sampling occasion.

Fig. 4: Powdery mildew visual severity (\%) on oak leaves from trees in three heightclasses on five sampling occasions. Data are averaged over both surfaces of all leaves 
from a tree. Error bars indicate the standard error of the mean (SEM) based on between leaves variance.

Fig. 5: Total incidence of colonies of other fungi in oak powdery mildew colonies over the period of study. Gray areas denote the leafless period; initial sample was taken as soon as powdery mildew colonies were visible.

Fig. 6: Distribution across trees of average abundance scores of fungi seen in sticky tape impressions of oak powdery mildew colonies. The score for a tree is the average of 2 sticky tape impressions taken from 20 leaves ( 2 branches, each bearing 10 leaves) each scored on a $0-3$ scale. Boxplots show the range, medians and quartiles of the average spore abundance score in a tree.

Fig. 7: Distribution of powdery mildew severity over trees, categorized by mean abundance scores of commensal fungi in the same tree on the same sampling occasion. Powdery mildew severity is the mean of the assessed leaves. Individual abundance scores are means from 2 sticky tape impressions (one on the upper leaf surface and one on the lower) taken from 20 leaves per tree ( 2 branches, bearing 10 leaves) on a single sampling occasion. Boxplots show the range, medians and quartiles of the powdery mildew severity. In all cases, means and medians are similar.

Fig. 8: Relationship between mean abundance score of fungi seen in sticky tape impressions of the assessed leaves, averaged over all impressions from each branch of each sampled tree, and mean powdery mildew severity on the same trees. Data from summer and autumn surveys are plotted together. Regression equations are shown for each year separately (a) Acremonium sp. (Percentage of variance accounted for by regression, $\mathrm{R}^{* 2}=12.5$, standard error of observations, s.e. $\left.=0.65\right)$. (b) 
Ampelomyces/Phoma sp. $\left(\mathrm{R}^{* 2}=48.4\right.$, s.e. $\left.=0.34\right)$. (c) L. australis $\left(\mathrm{R}^{* 2}=28.4\right.$, s.e. $\left.=0.6\right) .(\mathrm{d})$ Trichoderma sp. $\left(\mathrm{R}^{* 2}=39.7\right.$. s.e. $\left.=0.62\right)$.

Fig. 9: Relationships between L. australis abundance (La) score and the scores of other fungi seen in sticky tape impressions of oak leaves. Each point represents the mean score from a branch, averaging over replicate slides and bot leaf surfaces. Separate lines are fitted for the cases where powdery mildew was present and absent. (a) Acremonium sp. (A): powdery mildew absent, Acremonium score $=0.24+0.03 \mathrm{La}(P=0.09)$; leaves with powdery mildew present $\mathrm{A}=0.73+0.17 \mathrm{La}(P=0.002)$. (b) Ampelomyces/Phoma sp. $(\mathrm{Ph})$ : never found in the absence of powdery mildew; powdery mildew present, $\mathrm{Ph}=0.19+0.12 \mathrm{La}(P=0.001)$. (c) Trichoderma sp.: powdery mildew absent, $\mathrm{T}=0.21+0.41 \mathrm{La}(P=0.4)$; powdery mildew present $\mathrm{T}=0.34+0.46 \mathrm{La}$ $(P<0.001)$. pm, powdery mildew. 
Table 1: Estimated variance of the random components which contributed to the observed differences in powdery mildew incidence and severity within the study area at Reading during 2005-7. Fixed effects were season, location and leaf surface.

\begin{tabular}{llc}
\hline & \multicolumn{2}{l}{ Variance component } \\
\cline { 2 - 3 } Random term & Incidence & Severity \\
\hline Between year & $0.07 \pm 0.07$ & $13.2 \pm 13.3$ \\
Between trees within location & $0.03 \pm 0.002$ & $0.48 \pm 0.35$ \\
Leaves within the canopy of each tree & $0.14 \pm 0.004$ & $16.9 \pm 0.46$ \\
\hline
\end{tabular}


Table 2: Estimated variance of the random components which contributed to the observed differences in incidence and score of fungi associated with oak powdery mildew within the study area at Reading during 2005-2007. Fixed effects were season, location and leaf surface.

\section{Variance component}

\section{Ampelomyces/ Acremonium L. australis Trichoderma}

\begin{tabular}{lcccc} 
Random term & Phoma sp. & sp. & & sp. \\
\hline Year & $0.18 \pm 0.20$ & $0.27 \pm 0.28$ & $0.09 \pm 0.09$ & $0.49 \pm 0.50$ \\
Tree & $0.003 \pm 0.002$ & $0.01 \pm 0.01$ & $0.001 \pm 0.002$ & $0.007 \pm 0.001$ \\
Leaves within the & $0.11 \pm 0.01$ & $0.2 \pm 0.02$ & $0.23 \pm 0.02$ & $0.26 \pm 0.020$ \\
canopy of each tree & & & & \\
\hline
\end{tabular}


Table 3: Incidence of the most common commensal fungi in sticky tape impressions of leaf surfaces of Quercus robur in leaf surfaces with and without powdery mildew.

Incidence of the fungal group

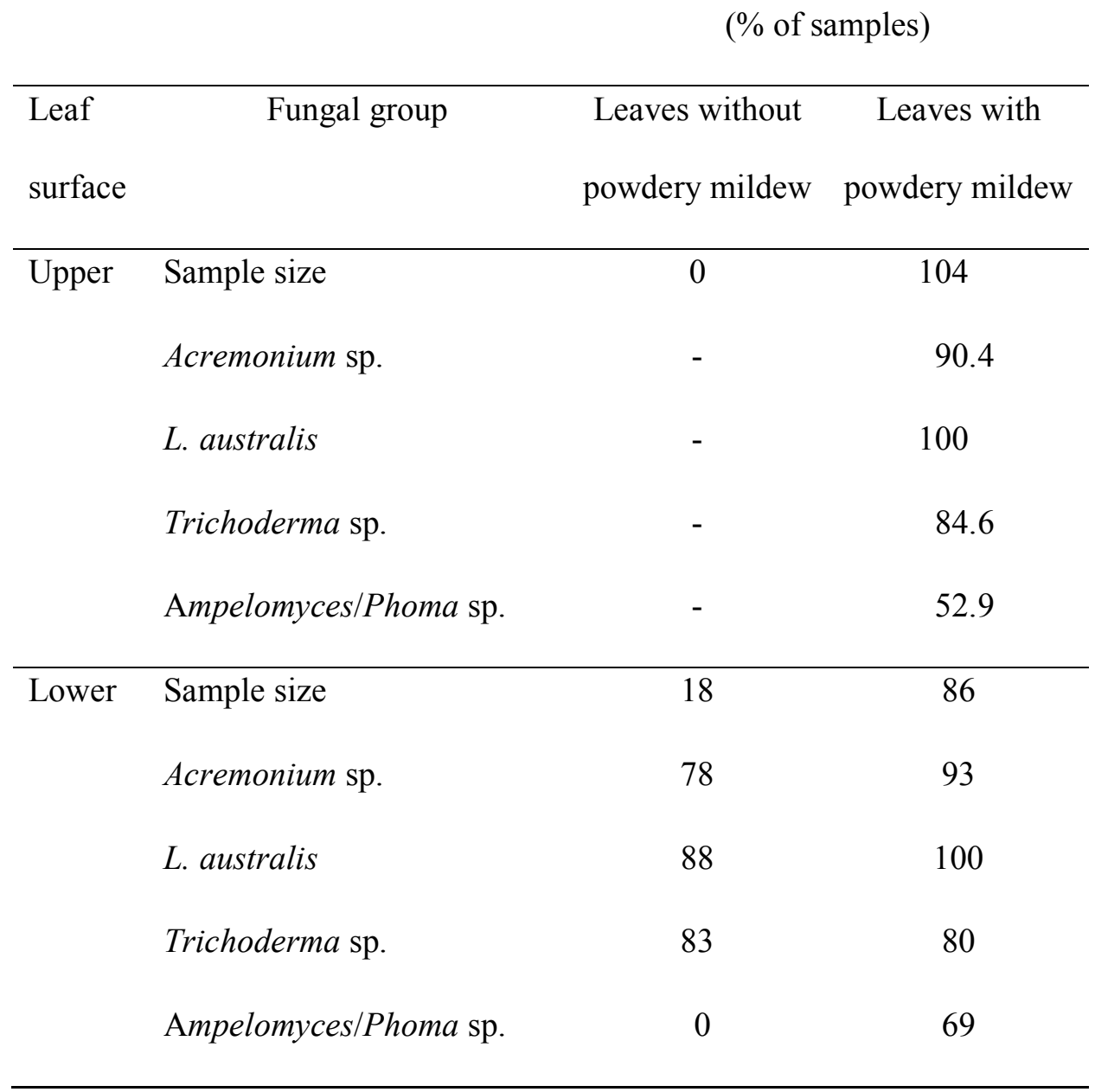

